\title{
"WE HAVE ALL LIVED AND BREATHED TEA." GENDERED MORAL ECONOMIES OF FACTORY TEA PRODUCTION IN WESTERN GEORGIA
}

\author{
KATARZYNA E. KRÓL
}

GRADUATE SCHOOL FOR SOCIAL RESEARCH, POLISH ACADEMY OF SCIENCES

\begin{abstract}
Scholarship on Georgian food and drinking culture has been expanding in the past decades. However, scholars have focused mostly on private spaces of food preparation and consumption, as well as on domestic practices of hospitality. This paper tries to expand the scope of these studies by looking at spaces previously omitted: namely spaces of industrial food production. Building on the results of fieldwork conducted in Western Georgia (the Samegrelo region) between 2016 and 2017, as well as several short field trips in 20I5, this paper focuses on gendered moral economies of tea (Camellia sinensis) production in a context of economic change in Georgia.

This paper follows people who produce one commodity: tea. Although not broadly considered a legitimate part of Georgian foodways, it is imprinted in the lives of the people who both used to and still do work in tea manufacturing. The analysis focuses on one main protagonist: a tea technologist employed at a factory. In so doing, it demonstrates the moral economies in which downgrading, migration and coping strategies are embedded.
\end{abstract}

KEYWORDS: Georgia, tea, factory work, gender, moral economy

"Georgian Prince Miha Eristavi first encountered tea during his travels across China in the I830s. Impressed with its taste he decided that he would take some seeds back to Georgia. At the time, exporting tea seeds from China was forbidden so the prince hid some seeds in a length of bamboo and smuggled it out of the country. On his return to Georgia he used the seeds to create the first tea plantations" (Carr 2018, 25). ${ }^{1}$

I A popular semi-legendary, promethean-like story about the origins of tea in Georgia, to be found on each blog entry and tourist website discussing Georgian tea, also recalled by some of my interlocutors. This royal motif is also used in branding by some of the tea companies. Although the majority of my interlocutors knew that the real popularity of tea came with the Soviet Union, they chose to emphasize the royal founding myth of tea plantations. If consumption is understood also as a symbolic act of "incorporating and performing the nation" (Muehlfried 2007, I0), "othering" tea by underlining how its consumption is not a part of traditional Georgian foodways could be seen as a negative performative act of drawing ethnic and political boundaries. 


\section{INTRODUCTION}

In recent years, Georgian food and wine culture has received an abundance of interest from both the wider public and academic scholars (e.g. Capalbo 20I6; Chatwin I997; Curro 2019; Goldstein 2013; Mühlfried 2005; Söderlind 2009; Tsitsishvili 2006). Georgia is indisputably a cradle of wine. However, there is another beverage casually overlooked by the scholarship analysing Georgian foodways, which demands scholarly attention: namely tea. Although tea consumption may not seem as characteristic for Georgia as for neighbouring countries like Azerbaijan and Turkey², tea remains one of the commodities that has irreversibly transformed not only the ecological landscape, but also the lives of thousands of Georgians.

Georgia held the position of the main tea producer in the Soviet Union, with 152,000 tons of tea harvested in 1985. The landscape and the lifestyles of the population were severely influenced by tea production: with nearly 70,000 hectares of land allocated to tea fields and around I80, ooo people employed at various stages of tea production (ENPARD 20I5). Growing, harvesting and manufacturing tea constituted a way of life for a number of villages in the subtropical parts of Georgia: "We have all lived and breathed tea", as one of my interlocutors put it. The site of my ethnographic research, referred to in this text as Town, is inhabited by around six thousand people, nearly exclusively Megrelians. ${ }^{3}$ Formerly, this was an important tea producing powerhouse; now it is a rather ruralised town with only one out of its former six factories still working. Shortly before my fieldwork started, the factory made a deal with China's Chedzani Ranrani Biotechnology for new investments as well as for tea orders, which provided a new hope and new dimension to the tea moral economies.

Tea (Camellia sinensis) is a labour-intensive commodity, globally relying on an availability of underpaid yet skilled workers. Growing tea also means profound changes in the local environment: it is grown on monoculture plantations, posing serious threats to local fauna and flora biodiversity. The intense use of pesticides and fertilizers required also creates environmental dangers. At the same time, tea is a knowledge-intensive commodity. Production cannot exist without a "knowledge economy", as Arnab Day (20I8) describes the foundation of a tea enterprise, combining scientific discourse, agrarian ideology and plantation practice in colonial Assam.

2 With distinct tea houses culture, serving as predominantly male spaces of socialization and leisure. In Georgia that style of tea consumption culture could be observed in the Adjara region and Kvemo Kartli (regions neighboring Turkey, and Azerbaijan respectively).

3 The Megrelians are generally considered to be a sub-group of the larger Georgian ethnicity, originally associated with the historical region of Megrelia (Samegrelo in Georgian) in western Georgia. The Megrelian language belongs to the Kartvelian family of languages, together with Georgian, Svan and Laz. 
This paper focuses on the gendered moral economies of tea production in Western Georgia in a context of economic change. However, by applying the approach of moral economy, I will focus on highlighting values and norms in order to challenge economistic views (cf. Hann 20IO). Applying such a perspective will shed light on the opaque logics and values that guide the livelihood practices of tea workers.

In the centre of my analysis I put one interlocutor - referred to in this text as Nino - a tea technologist employed at the factory. I supplement this with data obtained from other employees of the same factory. By observing the everyday realms of the post-socialist tea factory, I ask a question about the values behind Nino's persistence in making tea (despite the very limited and irregular economic remuneration she receives). In doing so, I want to enrich the existing understanding of the situation of Georgian women as female factory workers in a post-transition, yet globalized, peripheral context. I also ask a question about what is acceptable or desirable in terms of tea related labour: it is in order to shed light on this, that I explore the attitudes of the women workers towards migration to Turkey. More broadly, this paper also aims at addressing a gap in anthropological scholarship on women's public spaces in the Caucasus. It does so by attending to the often omitted public spaces of production occupied by women in Georgia, instead of looking at the private spaces of (re)production and consumption which have been keenly explored in recent years (cf. Curro 2019; Linderman 20II; Manning 2007; Mühlfried 2005; Tsitsishvili 2006; Tuite 2005).

\section{THEORETICAL APPROACH}

Scholarship on gendered spaces of food processing and manufacturing has shown that it is not only post-socialist, but global horticulture chains that depend on underpaid and disadvantaged female workers (Allen and Sachs 20I2, 28). This type of work is characterized by its seasonal and flexible nature, failing to provide a stable source of income and security. Despite the number of studies on agricultural production, also in the post-socialist context (i.a. Mincyte 20I4; Mroczkowska 20I9), the material aspects of gender relations throughout the food system remain understudied (cf. Allen and Sachs 2012). Thus, it is worth asking about the gendered motivations and values ascribed to this type of work.

Scholars have shown how the specific context of industrial food production in the post-socialist context is linked to discussions on labour, and inevitably leads to comparison with the global market (Caldwell 2009, I7). One of the best examples of such ethnographies is provided by Elizabeth Dunn (2004), who observed the economic transition experienced by factory workers and explored what happens at the junctions of industrial spaces of food production in the Alima Gerber factory in Poland. In so doing, she demonstrates the links between models of management and the ways in 
which workers relate to the commodities they produce, but maybe more importantly, to one another, and thus is able to highlight the alienating processes inscribed in capitalist production. Scholars have also problematized the question of "compliance with marketization" observed among workers in the first decade after the post-socialist transformation (Weiner 2005). Although broad engagement with this argument is beyond the scope of this paper, it is worth noting that my interlocutors expressed criticism towards marketization and the changes this entailed in the mode of production of tea. In this paper, however, I am more interested in the small-scale practices of everyday moral economies among female factory workers.

Bearing in mind the rich discussion about theoretical approaches towards the concept of moral economy in anthropology (c.f. Palomera and Vetta 2016), and the classical work by E.P. Thompson (197I) who highlighted the inseparable entanglement of both morality and economy, I choose to follow the path of Dimitra Kofti. Kofti argues that moral economy as a concept in anthropology can and should be used not only to investigate social struggles (e.g. rebellion, cf. Scott 1976), but "also people's everyday lives and struggles, and [...] muted responses to inequality and precarity" $(2016,435)$. She focuses on precarity under flexible capitalism to show how collective moral confinements and individual acts and perceptions are intertwined. Therefore, her approach enables research into "moral incentives and relations of dependency, without losing sight of their dynamic actions" (2016, 435). Kofti introduces the notion of "the moral economy of flexible production" $(2016,439)$, to show how women in flexible capitalism occupying precarious positions morally prioritize kin and household obligations over solidarity with colleagues. In my paper, however, I show an opposite process taking place in the factory: exploring how Nino prioritizes community, and thus creates community-oriented moral economies of tea production.

In recent years, we can observe an increased interest in plantations as field sites for anthropologists and multidisciplinary research teams informed by postcolonial studies and working within the multi-species paradigm (Chao 2018; Kumpf 2020; Perfecto et. al. 2019). These define plantations as spaces of "cultivation through coercion" (Tsing 2OI2, I48) that imply nature commodification, a prioritization of production and an implementation of techno-scientific control over crops (Tsing 20I2; Kumpf 2020). Drawing on ecologically informed approaches, these studies shift the paradigm to a more holistic approach in thinking about human and nonhuman life. Tsing et. al. show that plantations can be seen as an exemplification of anthropogenic disturbances of the landscape (Tsing et. al. 2019, I87), caused by "modular simplifications" (reducing the number of species on a specific area to just one chosen kind) and "feral proliferations" (the rise and spread of diseases caused by ecological unbalance). Further they underline that "plantations create monocrops to make it possible for coerced and alienated labor - and more recently, machines - to tend crops without the care that farming otherwise requires" (2019, I89). This article will not engage in a detailed 
discussion with this approach, but nevertheless I would like to signal important differences that emerge from my data. Undoubtedly, tea has changed the ecological landscape of western Georgia. However, as I will show below, in the case of the de-industrialized context of tea production in the Town we observe different processes from those mentioned above. For Nino in particular, the decision to continue working in tea production was founded in an ethics of care for local people and an affective relationship with tea itself: thus, she regretted when its production was abandoned or when she felt its modes of production were becoming less quality based. I would also find it problematic to claim that she is alienated from her labour. More nuanced differences in the post-socialist and post-colonial plantation landscapes would definitely be worth discussing in detail. This paper, however, puts humans in the centre of its interest. I look at tea rather in terms of a commodity, the production of which creates particular types of (moral) economies, than as a non-human agent.

\section{METHODOLOGY}

This study is a result of ethnographic fieldwork conducted between 2016 and 2017 in the Samegrelo region of Georgia. ${ }^{4}$ In this article, I focus on the data gathered in one location, the Town, although in my analysis I have also used data and insights obtained during several preliminary study visits, taking place between 2014 and 2016 in the regions of Adjara, Guria, Imereti, Samegrelo and Abkhazias, as before choosing my main field site, I mapped and visited several other locations known for tea production.

During the fieldwork, I used traditional ethnographic methods, mainly participant and non-participant observation. In particular, I conducted biographical and semi-structured interviews, both recorded and unrecorded. ${ }^{6}$ The majority of my data

4 This research entitled: "Post Socialism in Georgia: an Anthropological Perspective on the Tea Industry" was financed by the Ministry of Science and Higher Education. It was based at the University of Warsaw between 2014 and 2018.

5 Despite the problematic status of Abkhazia after the civil war, as a de facto state, the Georgian government and the majority of the United Nations' countries recognize Abkhazia as part of Georgia. Also for my interlocutors the claims of Abkhazia to belong to Georgia were unquestioned. The Georgian Subtropical Agricultural Institute was located in Sukhumi (Abkhazia), and as such appears frequently in biographical narratives about obtaining education and training on tea during my research project. Thus, to avoid any further discussion on the political matter on Abkhazia, I choose to apply an emic attitude reflecting my interlocutors' perspective.

6 The further into the course of my field research, the less I used the recorder. Also, some of the semi-interviews occurred spontaneously during my collective work with the interlocutors and as such were only recovered later in the forms of field notes and head notes. 
comes from the experience of collective work and sharing everyday arduous tasks at the factory. I talked to people working in the tea factory; the director, the vice-director, mechanics, tea technologists, tea pluckers, the owners of the "cantine" located at the premises of the factory, representatives of local government and NGOs and other inhabitants of the town.

At the beginning of my research, during my preliminary short visits, I did not feel comfortable enough with my fluency in Georgian, although I had a substantial understanding of the language. Therefore, I would use Russian to conduct interviews whenever possible (which allowed me to talk mostly to middle-aged or senior men, who due to education or army service spoke good Russian). Before returning to the field, I improved my Georgian, but for multiple reasons ended up choosing a bilingual community (Georgian-Megrelian) as my final research destination. Megrelian is an unwritten language belonging to the indigenous Kartvelian language family, distinct from the national language of the Georgian state. ${ }^{7}$ The politics of using Megrelian in public and private spaces differ, but it is spoken in different social contexts, including in many cases in the domain of work (Broers 20I2). And indeed, Megrelian remained the language of choice and convenience in the factory and tea fields. I had to accept the fact that I would only speak the official language, as my knowledge of the language of convenience of my interlocutors remained rudimentary. This posed some limitations, especially in the beginning of the field research of which I am aware. I find some consolation though in the work of Michael Herzfeld, who points out the importance of gesture and "informal modes of embodiment" (2009, I3I) in doing fieldwork as a process of gaining access to culturally intimate spaces.

\section{THE PROTAGONIST: NINO}

My stay and research at the factory was possible primarily thanks to the hospitality of Nino, a tea technologist. During a preliminary study visit in Georgia, I came across information about her work at the factory and her attempts to establish a tea cooperative. Since we could not meet in Tbilisi, I found her number through a long list of friends, acquaintances and strangers (a perfectly common and effective strategy in Georgia) and scheduled a meeting in Town. After our interview and her expressions of willingness to help me with my project, I had to convince the director of the factory. Although not ecstatic about my plans, he accepted my presence at the factory.

7 It is beyond the scope of this article to refer to the ethno-linguistic discussion about the status of the Megrelians, but it is important to note that the debate about this has been and still is shaped by the political factors: while Russian linguists and ethnographers defined the Megrelians as a separate natsional'nost' during the Soviet period, Georgian intellectuals criticise such attempts as a separatist threat (Broers 2004). 
Nino was at the time of my fieldwork in her early seventies and had worked as a tea technologist for the majority of her professional life. She lived nearby the factory, in a khrushchyovka style building. ${ }^{8}$ From the balcony, she could see the factory. She never married, nor had children. The fact of departing from dominant gendered life course scenarios caused endless unrefined jokes and often painful comments from male employees. Occasionally they would even question Nino's sanity, which indicates the extent to which the dominant model of life is discursively protected and reproduced. In her male colleagues' view, she was an example of an "improper women" who chose work over family. Although she did not start a family of her own, she was close to her brother and his wife who lived in a family house in a village just outside Town and whom she often visited to help with the harvest of hazelnuts, vegetables and fruits.

We would spend together five days a week at the factory: from the morning when Nino would open the door, till the afternoon when she closed it. On the days of the delivery of fresh tea leaves, I would also come back in the evening to observe weighing, unpacking and price negotiation. I would use this as an opportunity to chat with tea picking teams. Nino, in her turn, would sometimes use it as an opportunity to comment on the unsatisfactory quality of the tea leaves provided by the team.

I decided to build my analysis about the gendered moral economies of tea production in the context of economic change around the story of one person: Nino. In the following sections, I will show how her biography embodies the processes which are the focus of this study. In order to contextualize this, in what follows, I sketch the historical background of current tea production conditions in the Town.

\section{STUDY SETTING - GEORGIAN TEA IN TRANSITION}

The collapse of the Soviet Union resulted in a deterioration of infrastructure and markets. For the tea industry, the civil war in Abkhazia (1992-1993) also meant the loss of the infrastructure of the Georgian Subtropical Agricultural Institute in Sukhumi, where some of my interlocutors studied. ${ }^{9}$ In parallel with Burawoy's observations from Hungary and Poland (and other post-socialist countries), Georgian workers soon "found themselves either without a job or working under ever more precarious con-

8 Khrushchyovka is a conversational name used for a type of low-cost apartment house, made of panel and brick, which were massively built in the USSR between the late 1950s and early 1980s. The name derives from Nikita Khrushchev, as most of these buildings were built during his leadership.

9 After the war, the Institute was moved to Kutaisi. A second institute, the Tea and Subtropical Cultures Research Institute in Anaseuli (Guria) also provided and still provides education on tea and other subtropical plants. 
ditions and in a rapidly polarizing society" (2013, 53I). What followed was a process of deindustrialization and de-modernization: "The socialism that they had spurned had now become the radiant past, whereas the promises of capitalism looked very tarnished" (Burawoy 20I3, 53I).

According to the Caucasus Research Resource Center, since the collapse of the Soviet Union more than twenty per cent of the Georgian population have emigrated (CRRC 2007). By 20I5, tea production in Georgia had declined to only around I,800 tons per year, with only I,700 hectares of tea gardens still used (ENPARD 2015). Recent years, however, have brought some new opportunities (or at least promises) and official plans for the re-cultivation of Georgian tea production on both national and international levels. ${ }^{10}$ It has been noted that tea could provide a stable source of income for impoverished rural communities, like Town in Western Georgia where only one of its six factories is still operating today.

Just before my fieldwork started, the factory in Town made a deal with China's Chedzani Ranrani Biotechnology for an investment worth $\$ 80,000$. The deal involved investments in machines, specialist training in China for selected (male) factory employees and guaranteed orders for tea. Tea collected in May and June, considered to be of the best quality, was later processed in Town and exported to China. Although the director of the factory claimed that the agreement came into existence by pure chance, it has to be seen in a broader scope. In 20I4, a substantial increase of Chinese investments (attaining an overall figure of $\$ 2 \mathrm{I} 8$ million) in Georgia could be observed, followed by the start of negotiations on a free trade agreement between the two countries in 20I6. ${ }^{\text {II }}$ These investments were linked to the so-called Belt and Road Initiative (Charaia and Papava 2017), a transit network designed to facilitate China's trade with the world. At that time, it seemed like Georgia could become a local hub for Chinese investments.

The collapse of the infrastructure and markets for Georgian tea after the fall of the Soviet Union has left many Town inhabitants, especially men, unemployed. Those who kept their jobs at the tea factory were employed in higher executive positions: like director and vice-director, sales managers, mechanics and drivers. Nino held the position of the main tea technologist, but actually was responsible for the whole production process: from assisting in receiving freshly picked leaves, through keeping an eye on the twisting, fermenting and drying processes, right through to packaging. Other women employed at the factory were responsible for bookkeeping and the hard physical

Io For example, several small tea holders have been recognized by the Georgian governmental agency the Agricultural Cooperative Development Agency (ACDA) - and have received funding support from an NGO coalition led by CARE-International, as part of the EU's European Neighbourhood Programme for Agriculture and Rural Development (ENPARD).

II http://www.economy.ge/page=news \&nw=I80\&s=saqartvelosa-da-chinets-shoris-tavisufalivachrobis-shesaxeb-xelshekruleba-gaformdeba\&lang=en. 
labour on the plantations, and for refining dried tea from any unwanted elements - like bits of stems or not twisted enough leaves. Thus, as I could observe, the gendered division of labour at the factory put women in the less privileged positions, both in terms of stability of employment (for example tea picking is seasonal piecework) and the remuneration received. Also, opportunities for professional development were not offered to women: as only men were selected to attend training in China. Most of the female factory workers did not have a family which would provide a support network, thus making them more prone to accept inferior work conditions. Lack of possible alternatives served as an effective demotivating factor to renegotiate work conditions. In the next sections I discuss local moral economies: first on the community level, and then on the individual scale. Nino will serve as a guide in both sections.

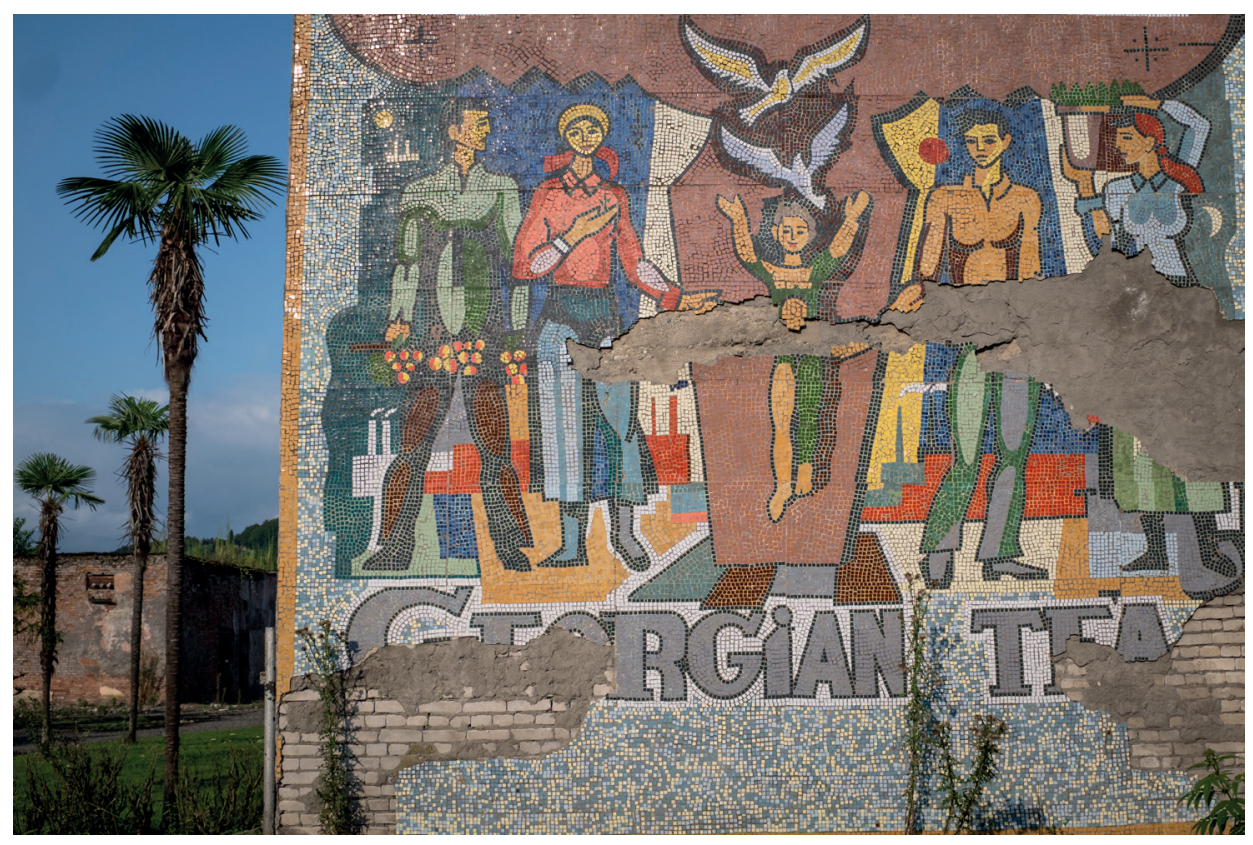

Fig. I. A mosaic on the wall of a closed tea factory, one of six that operated in Town.

Photo by Ian McNaught Davis

\section{COMMUNITY-ORIENTED MORAL ECONOMIES OF TEA: DOWNGRADING AND MIGRATION}

Downgrading and migration are the two major features observable in professional biographies after the collapse of the Soviet Union tea production system. Although providing income, they both conflict with Nino and other workers' moral economies that put a high value on the notion of community. 
The first years after the fall of the Soviet Union affected both genders differently: women had to face unemployment, a retreat to the private spaces of reproduction and shrinking state support for elder family members (e.g. Pine 2002). The need to provide for families, provoked by high unemployment rates among men who simultaneously lost their traditional breadwinner's position, conflicted with traditional expectations from Georgian women. In these first years of independence, characterized by rampant unemployment, women on average did significantly better than their partners: they were more flexible and more open to "downgrading" (Sumbadze and Tarkhan-Mouravi 2003), for example by accepting housekeeping or trading jobs despite higher qualifications.

Thus, it was not women who experienced the "retreat to the household" (to borrow a famous phrase from Frances Pine, 2002), but rather first and foremost their male spouses, unable to find new employment or unwilling to accept jobs below their qualifications. ${ }^{12} \mathrm{My}$ interlocutors expressed similar opinions to those mentioned by Elizabeth C. Dunn (2008) when describing the post-transformative condition of Georgian everydayness: namely experiencing an abandonment from the state. This put even more pressure on women to find ways to make ends meet, which often meant migration. In order to provide for their families, they would respond to the global demand for migrant female labour (Lundkvist-Houndoumadi 20IO) or start "shuttle trading" careers (Bloch 20II). Bloch also notes, that they devoted a lot of emotional labour to hiding the fact of being the main breadwinners in the families. Similar struggles around the gendered division of labour in the household, especially in times of progressive economic deprivation have been observed in Georgia (Paulovich 2016). Most importantly, as Alexia Bloch has observed: "women entrepreneurs' accounts highlight not only anxieties about proper forms of labor" (2OII, 3I8), but also a feeling of shame of becoming entrepreneurs involved in small trade, as this stood against all the values they had internalized as Soviet citizens. Nino, who had to provide for herself and occasionally support her brother's family, experienced a similar episode in her biography: "After the civil war, people left - some abroad, some to the bigger cities. I worked in trade. Years passed and I gradually became convinced that this was not for me". The feeling of performing an improper form of labour, even though the job provided her with a basic income, made her uneasy. The new job could not offer the feeling of fulfilment and sense of community that she had experienced in her previous job at the factory. Even after her return to tea production, the likelihood of keeping the factory running remained uncertain. Some hopes, however, have been brought by the Chinese investments in Town.

I2 Women were also more active in the fast developing bed-and-breakfast and hostel sector. They were also more often employed by international organizations and were targeted as small grant receivers by development projects (Sumbadze and Tarkhan-Mouravi 2003). 
Reflecting on the changes brought by the Chinese investments for local tea production, my interlocutors expressed mixed feelings. On the one hand, they felt pride and enthusiasm about the agreement, as it seemed to guarantee higher prices for tea and thus better and more regular wages for the employees. It was also believed that it would grant more workplaces and increase the acreage of the tea fields in use. For Nino, Chinese investment meant that more women would be able to work in the Samegrelo region and that economic migration would stop or at least diminish.

Contemporary attitudes towards female migration remain fairly unchanged to the dominant tendencies in the Soviet Union. Working class women are more prone to experience a backlash, whereas the migration of educated and highly skilled women is usually valued positively and considered prestigious. According to Yalçın-Heckmann: "Seasonal or long-term migrations for work and education were relatively common in the Caucasian republics of the Soviet Union" (2010, I23). It was considered normal for men to seek better material conditions in order to provide for their families and invest in the family house. Likewise, some of the female protagonists of my research who completed university degree training in tea technology shared the experience of migration to Tbilisi or Sukhumi for education. Later, they would spend some years in a state assigned location, potentially meet future spouses and decide to settle down. In the narratives I collected, the experience of moving away was perceived positively: more as an adventure and a reason to be proud of one's education and achievements. However, the perception of migration has changed after the collapse of the Soviet Union. The need to look for work outside one's place of residence has been caused mostly by war and impoverishment (Shahnazaryan 2005, 236). The contemporary global trend of the increased participation of women in labour migration has also been observed in the Black Sea Region: with Greece and Turkey especially popular destinations (Ferry 2015). Favourable conditions with regard to Turkish-Georgian migrant exchange and the possibility to work in tea fields made it a landing place also for women from the Samegrelo region. Yet, working class female migrants, like in many other places, have to deal with ambivalent judgements on the part of their spouses and wider society (Lundkvist-Houndoumadi 20I0; Ferry 2015). The reason for a particular attitude towards female workers choosing Turkey in the public imagination is fuelled by occasional sensational news about Georgian women working in Turkish brothels. In Nino's view, migration was dangerous for women and unsuitable for a proper family life. On multiple occasions, she would commiserate over the fate of women and men who were "forced" to work in Turkey as tea pickers. Aside from migration misgivings, for Nino the misery stems from the fact that Turkish tea is not picked by hand, but is cut with scissors or even harvesters. It is believed that workers are treated in an inhumane way, as only the amount of harvested tea matters. Since work in Turkish plantations is considered backbreaking and as being quantity not quality oriented (and thus not in need of skilled and delicate female hands), men also 
are recruited for this work. On rare occasions, couples also choose this type of seasonal migrant work. Even though work on Turkish plantations is considered much harder than that available locally, it offers undeniable advantages: it is fairly secure and much better paid, with the daily wages up to ten times higher. Again, economic and moral calculations do not go hand in hand.

Anthropological literature shows how ideas about being a "proper" Georgian woman are embedded in the values of a patriarchal society, underlining motherhood as the key role for a woman (Gavashelishvili 2017, 27). Consequently, migration poses a threat to the role of a mother "devoted to family and homeland" (Gavashelishvili $2017,27)$. This has resulted in seeing migration as a risky and undesirable path, especially for women. For Nino, therefore, opportunities allowing women to work in Town are important for two reasons. First, it would secure a continuation of the tea heritage in the region: keeping local people seems vital in her view to ensure the revival of tea production, which could easily be jeopardized by Turkish plantations that already have more economic power and now also a workforce. Secondly, it would defend the moral economies that for her tea represents: by offering employment to local people. Nino had a strong ethos of hard work and duty for the land and the local community:

I was born in a family of hard working peasants. I remember when I was in the third grade, after finishing school in the afternoon, I followed my mother to the tea plantation and picked I8kg of tea leaves [...]. I was always in love with tea. In Tbilisi, I bought all brands of imported tea and made sure that we could produce a significantly better quality Georgian tea at a lower price. When I returned to Town (after the civil war), I saw the on-going destruction of the remaining tea bushes. And yet tea could bring great good to the people who stayed in the village. Therefore, I started making tea again.

The moral economies of tea production applied by Nino were not only oriented around securing work for local people. She also had a strong feeling of belonging: when she recalled the collective farms (Georgian: зммдау э5 5 mos), she would underline the cooperation and sense of local community it created. A community that was endangered nowadays as people struggled to support their families without secure jobs. This lack of stable employment has stimulated different coping strategies. Below, I discuss one of them.

\section{MORAL ECONOMIES OF APPROPRIATION: COPING STRATEGIES}

On a typically hot and humid September day I entered the main building of the factory, where I would usually find Nino getting ready for another day of selecting and packing tea. Normally, I would smell the specific aroma of fermenting tea 
leaves - compared by some to freshly cut grass - and a bit of dust in the air, but today there was something else: a sweet aroma of fruit and hazelnuts. I found Nino in the back room, putting on her blue working apron and asked her about the nice aroma in the air. At first she did not say anything, just smiled impishly with a twinkle in her eyes. She asked me if I hadn't seen Kote (the vice director of the factory) anywhere on my way, and when I replied in the negative, she led me to one of the newly obtained tea driers. Brought to the factory on lease together with other machines as part of the agreement with Chinese investors, this machine sparked ambivalent feelings among the factory crew. The new machines were not appreciated by the mechanics, as they could not repair them - even if they knew how to do so, the lease agreements obliged the factory to use the authorized company for regular check-ups and even the tiniest repairs. For mechanics who used to repair all the machines at the factory and even build some machines by themselves, this felt disrespectful, if not insulting. Also the tag with Chinese letters placed in the central part of the drier provided a silent, but persistent reminder of the foreign origin of the machine. I followed her. When she opened the drier, I saw threaded hazelnuts being prepared for churchkhela $^{13}$ (Georgian:


Nino and other women giggled when they saw my bemusement.

The above incident demonstrates a coping strategy applied by Nino and other female workers in order to secure the production of homemade preserves and thus adhere to culturally prescribed gendered roles that can helpfully be described through de Certeau's term of the tactical practices of la perruque $(1984,25)$. With this term de Certeau denotes a subversive act performed by a worker when she works for herself instead of working for the employer, and uses machines/materials/resources provided by the employer to pursue her own projects. But as de Certeau observes, "it differs from pilfering in that nothing of material value is stolen" $(1984,25)$. What Nino and other workers did with the new Chinese tea drier did not harm the timeline of tea production. It also did not pose any threat to the machine itself. Instead, it fulfilled their need to stock the pantry for winter with dried fruit, and made churchkhela production much faster and easier. They realized that with the capacities of the drier they can prepare more fruit much faster, without having to count on rainless weather. And even if the vice director was aware of this practice - as it was hardly possible to

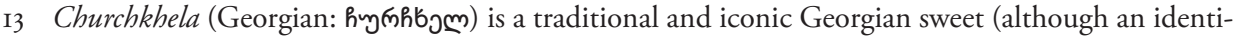
cal dessert is known under different names in other Caucasian countries, as well as Cyprus and Turkey). After nuts have been soaked in water for some time and threaded, they have to be dried in the sun (traditionally) and later dipped in grape juice thickened with flour several times to achieve the desired volume. After this, churchkhela is left to dry in the sun, although some eat it while still fresh. If prepared in the right manner, it can be stored for several months. It is usually prepared in the autumn, when fresh nuts and grapes are available. 
ignore the characteristic aroma of drying hazelnuts - he turned a blind eye to it. In de Certeau's terms, such practices transform the time and work of the worker from that "owned" by the employer into the temporary practice of the individual. My interlocutors were drying fruit in the guise of work: somehow in addition to performing work related tasks, they were also doing what was expected from them as women and wives, in other words preparing supplies for the winter months. Simultaneously, they were negotiating the nature of the space of work: the factory was no longer a public space where paid work was being delivered, but now also a privatized space of homely food production. I interpret this as a moment of bridging: of old habits on the one hand and the application of new moral economies of coping on the other. By doing so, my interlocutors were practicing the moral economies of coping strategies in turbulent times. Despite their precarious economic position, they were committed to prepare homemade preserves, which presumably would mean savings (in terms of energy and food expenses in the winter months), but also they were opposing the market logic which had started to deprive them of their traditional way of life.

Anthropological research has shown how receiving and hosting guests is focused on gendered practices of performing the roles of a good host and hostess (Polese 2009). Moreover, as Constanza Curro has noted, "excess" can become a pattern of "proper" hospitality, drawing moral boundaries and influencing the process of personhood making on both individual and collective levels (2019). The practice that Nino and her colleagues were engaging in should not only be seen as saving time, but also in terms of fulfilling gendered expectations regarding homemade food in wider kinship networks. Parallels can be found here to the work of Dunn (20I6), who looks at material objects to investigate how internally displaced people (IDPs) recreate their lives and what role the material world, food being of pivotal importance, plays in this process. To investigate the reasons behind a perceived lack of ontological value of donated material objects amongst IDPs, Dunn looks at the homemade preserves that she rather paradoxically found to be available at the IDP camp. This led her to the conclusion that it is the provenance of preserved food, embedded in kinship networks so important in Georgian sociality, that turned the ontological status of products into real food (Dunn 2016, 293). A rich body of research on Georgian foodways (with the above-mentioned work at its centre) show how food preparation and display is central to the proper performance of gendered roles in Georgian society (Curro 2019; Linderman 20II; Manning 2007; Mühlfried 2005; Tsitsishvili 2006; Tuite 2005). My interlocutors ${ }^{14}$, amongst them those who did not own a proper house with a garden

I4 My field site was also affected by the Georgian-Abkhaz civil war (1992-1993), resulting in the mass forced displacement of people. The Megrelians of Abkhazia were displaced to other parts of Georgia, with the majority now residing in the Zugdidi area (Samegrelo region) and the capital Tbilisi. Some of my interlocutors and factory employees had experienced displacement, and even after all these 
allowing them to grow and prepare homemade preserves, were appropriating factory machines in order to be a part of kinship networks and homemade food exchange. In doing so, they were responding to economic deprivation and looking for ways to cope with an unprivileged position through an everyday act of preparing preserves.



Fig. 2. Inside the tea factory. Tea leaves picked earlier in the day are left to dry. Photo by Ian McNaught Davis

\section{CONCLUSIONS}

This paper explores the moral economies of tea production in times of economic change. It examines the experiences of women who had to face the casualization and informalization of work conditions, while also fulfilling the often contradictory expectations posed by a patriarchal society in times of social, cultural and economic turmoil. It looks at the small actions and gestures of everyday life in order to investigate the hierarchies of values applied by Nino and other female factory workers guiding their choices and actions.

years were unable to fully reestablish their lives: for example by buying properties of their own. This had a serious impact on their traditional everyday foodways, like for instance the preparation of homemade preserves or wine (cf. Dunn 2014 on IDPs after the Georgian-Russian war in 2008). 
Nino, who became the main protagonist of this paper, started her adventure with tea in the times of the Soviet Union, experienced the transition to a market economy and now found herself as a subject of an unexpected international agreement with a Chinese investor. I show Nino as an example of a person who opposes the idea of unlearning the rules of being a good socialist citizen and instead tries to apply a community-oriented moral economy (cf. Bloch 20II) while producing tea. I explain her unfavourable opinions on two alternative ways of making ends meet, which are undesirable due to the fact that they fail to nurture a sense of community (trade) or even pose a symbolic threat to the community (migration). As a result, I propose to look at her ideas and practices as an example of "community-oriented moral economies of tea".

The women working in the factory use machines in order to secure the right amount of homemade food preserves for winter. I interpret this as a quiet, but important action against the logic of economic deprivation. By appropriating machines, workers were able to make highly valued homemade sweets, which will later enable them to be part of informal food exchanges. Thus, the values of community were prioritized over those of private property and work ethics. For Nino, it was also community oriented moralities that lay at the heart of her decision to go back into tea production and give up trade. The idea to provide work for the local people of Town, as well as a product of high quality and affordable price was prioritized in her calculation over individual values: understood primarily as monetary remuneration. Also her view on migration was influenced by moral judgments about the misery and hardships connected to migration, as well as the threat it poses to the integrity of the local community.

The concept of moral economy is for the most part focused on studying social groups, especially those excluded from dominant roles in social development. By focusing on observing the everyday practices of my interlocutors, such as their acts of compliance, struggles and small-scale solutions, I support Kofti's claim for the usefulness of such a framework for analyzing individual practices and ideas. My data shows major differences in creating moral economies from the ones described by Kofti, pointing to the need for more research on local conditioning and specificities of morally embedded economies of the post-socialist area in times of flexible capitalism.

\section{ACKNOWLEDGMENTS}

First and foremost, I am very grateful to my interlocutor, referred to in this text as Nino, for all her help. I am grateful to Iwona Kaliszewska and Renata Hryciuk for their valuable comments on drafts of this article, and to two anonymous reviewers and editors of Ethnologia Polona for their very constructive criticism and suggestions. I am grateful to Ian McNaught Davis for allowing me to reproduce his photographs in this paper and for being a great support whilst I was in the field. 


\section{REFERENCES}

Alexia, Bloch. 20II. "Emotion work, shame, and post-Soviet women entrepreneurs: negotiating ideals of gender and labor in a global economy." Identities: Global Studies in Culture and Power 4 (I8), 3I7-35I.

Allen, Patricia, and Carolyn Sachs. 2007. "Women and food chains: the gendered politics of food." In Taking Food Public. Redefining Foodways in a Changing World, edited by Psyche Williams-Forson and Carole Counihan, 23-40, London and New York: Routledge.

Broers, Laurence. 2004. Containing the Nation, Building the State: Coping with Nationalism, Minorities and Conflict in Post-Soviet Georgia. Ph.D. diss., University of London School of Oriental and African Studies.

Broers, Laurence. 20I2. "'Two sons of one mother': nested identities and centre-periphery politics in post-Soviet Georgia." In When the Elephant Broke Out of the Zoo: A Festschrift for Donald Rayfield, edited by Andreas Schönle, 234-267, CA: Stanford: Stanford University Press.

Burawoy, Michael. 20I3. "Ethnographic fallacies: reflections on labour studies in the era of market fundamentalism." Work, Employment and Society 3 (27), 526-536.

Caldwell, Melissa. 2009. "Introduction: food and everyday life after state socialism." In Food and Everyday Life in the Postsocialist World, edited by Melissa Caldewell, I-27, Bloomington, Indianapolis: Indiana University Press.

Capalbo, Carla. 2016. Tasting Georgia: A Food and Wine Journey in the Caucasus with Over 70 Recipes. Northampton: MA.

Carr, Mike K. V., ed. 2018. Advances in Tea Agronomy. Cambridge: Cambridge University Press.

Caucasus Research Resource Centres (CRRC). 2007. Migration and Return in Georgia: Trends, Assessments, and Potential. Report submitted to the Danish Refugee Council.

Chao, Sophie. 2018. "Seed care in the palm oil sector." Environmental Humanities 2 (IO), 42I-446.

Charaia, Vakhtang, and Vladimer Papava. 2017. "Belt and road initiative: Implications for Georgia and China-Georgia economic relations.” China International Studies 67, I22-139.

Chatterjee, Piya. 200I. A Time for Tea. Women, Labor, and Post/Colonial Politics on an Indian Plantation. Durham and London: Duke University Press.

Chatwin, Mary Ellen.1997. Socio-cultural Transformation and Foodways in the Republic of Georgia 1989-1994, Tbilisi: Metsniereba Press.

Certeau, Michel de. 1984. The Practice of Everyday Life. Berkeley: University of California Press.

Curro, Constanza. 2019. "Excessive hospitality: personhood, moral boundaries and domination around the Georgian table." Journal of Consumer Culture 2 (20), 216-234.

Day, Arnab. 2018. Tea Environments and Plantation Culture. Cambridge: Cambridge University Press.

Dunn, Elizabeth Cullen. 2004. Privatizing Poland: Baby Food, Big Business, and the Remaking of Labor. London: Cornell University Press.

Dunn, Elizabeth Cullen. 2008. "Postsocialist spores: disease, bodies, and the state in the Republic of Georgia." American Ethnologist 35 (2), 243-258.

Dunn, Elizabeth Cullen. 20r6. "Humanitarianism, displacement, and the pplitics of nothing in postwar Georgia." Slavic Review 2 (73), 287-306.

Dragadze, Tamara. 1988. Rural Families in Soviet Georgia. New York: Routledge.

Ferry, Maroussia. 2015. "Georgian migrants in Turkey: reconstruction of gender and family dynamics." In Interdisciplinary Studies on Central and Eastern Europe Series: Security, Democracy and Development in the Southern Caucasus and the Black Sea Region, edited by Nodia Ghia, and Christoph H. Stefes, I59-I82, Pieterlen: Lang A\&G International Academic Publishers.

Gavashelishvili, Elene. 20I7. "Childless women in Georgia. Between religious restrictions and medical opportunities." Anthropology of the Middle East I(13), 24-42. 
Goldstein, Darra. 2013. The Georgian Feast: The Vibrant Culture and Savory Food of the Republic of Georgia. Berkeley, Los Angeles, London: University of California Press.

Hann, Chris. 2010. "Moral economy." In The Human Economy: A Citizen's Guide, edited by Hart Keith, Jean-Louis Laville and Antonio David Cattani, I87-198, Cambridge: Polity Press.

Herzfeld, Michael. 2009. "The cultural politics of gesture. Reflections on the embodiment of ethnographic practice." Ethnography 2 (IO), I3I-I52.

Jegathesan, Mythri, 20I9. Tea and Solidarity. Tamil Women and Work in Postwar Sri Lanka. Seattle: University of Washington Press.

Khalvashi, Tamta. 20r8. "The horizons of Medea: economies and cosmologies of dispossession in Georgia." The Journal of the Royal Anthropological Institute 4 (24), 804-825.

Kochlamazashvili, Irakli, and Nino Kakulia. 2015. The Georgian Tea Sector: A Value Chain Study. ENPARD - European Neighbourhood Programme for Agriculture and Rural Development. http://enpard.ge/en/wp-content/uploads/2015/05/TeaValueChainAnalysis_ENG.pdf (accessed I3.10.2020).

Kofti, Dimitra. 20I6. "Moral economy of flexible production: fabricating precarity between the conveyor belt and the household." Anthropological Theory 4 (I6), 433-453.

Kumpf, Desirée. 2020. "Organic taste and labour on Indian tea plantations." Social Anthropology 4, I-I4. https://doi.org/Io.IIII/I469-8676.I295I.

Linderman, Laura Joy. 20II. "The gendered feast: Experiencing a Georgian Supra." Anthropology of East Europe Review 2 (29), 23-50.

Lundkvist-Houndoumadi, Margharita. 20I0. "Treading on the fine line between self-sacrifice and immorality: Narratives of emigrated Georgian women." Transcience Journal I(2), 50-70.

Manning, Paul. 2007. "Socialist Supras and drinking democratically: changing images of the Georgian feast and Georgian society from socialism to post-socialism." http://www.mapageweb.umontreal. ca/tuitekj/cours/Manning-Supra.pdf (accessed I3.IO.2020).

Manning, Paul, and Ann Uplisashvili. 2007. "'Our Beer': ethnographic brands in postsocialist Georgia." American Anthropologist 4 (I09), 626-64I.

Mincyte, Diana. 20I4. "Raw milk, raw power: states of (mis)trust." Gastronomica 4 (I4), 44-5I.

Mroczkowska, Joanna. 2019. "Pork politics: the scales of home-made food in Eastern Poland." Appetite, I4O, 223-230.

Mühlfried, Florian. 2005. "Banquets, grant-eaters and the red intelligentsia in post-Soviet Georgia." Central Eurasian Studies Review I (4), I6-I9.

Mühlfried, Florian. 2007. "Sharing the same blood - culture and cuisine in the Republic of Georgia." Anthropology of Food [Online], $\mathrm{S}_{3}$, (accessed I0.IO.2020).

Palomera, Jaime, and Theodora Vetta. 2016. "Moral economy: Rethinking a radical concept." Anthropological Theory 4 (I6), 413-432.

Paulovich, Natallia. 2016. "A breadwinner or a housewife? Agency in the everyday image of the Georgian woman." Anthropology of the Contemporary Middle East and Central Eurasia 2 (3), 24-44.

Perfecto, Ivette, and M. Estelí Jiménez-Soto, John Vandermeer. 20I9. "Coffee landscapes shaping the anthropocene: forced simplification on a complex agroecological landscape." Current Anthropology, S2O (6o), 236-250.

Pine, Frances T. 2002. "Retreat to the household? Gendered domains in postsocialist Poland." In Postsocialism: Ideals, Ideologies and Practices in Eurasia, edited by Chris Hann, 95-II3, NY: Routledge.

Polese, Abel. 2009. "The guest at the dining table: economic transition and the reshaping of hospitality, reflections from Batumi and Odessa." The Anthropology of East Europe Review I (27), 65-77. 
Scott James. 1976. The Moral Economy of the Peasant: Rebellion and Subsistence in Southeast Asia. New Haven, CT: Yale University Press.

Shahnazaryan, Nona. 2005. "The virtual widows of migrant husbands in war-torn Mountainous Karabagh." In Generations, Kinship and Care: Gendered Provisions of Social Security in Central Eastern Europe, edited by Haukanes Haldis, and Frances Pine, 23I-266, Bergen: University of Bergen.

Söderlind, Ulrica. 2009. "Introduction to the Foodways of Georgia." Caucasus Journal of Social Sciences I (2), 7I-87.

Sumbadze, Nana, and Giorgi Tarkhan-Mouravi. 2003. Transition to Adulthood in Georgia: Dynamics of Generational and Gender Roles in Post-totalitarian Society. http://pdc.ceu.hu/archive/oooo2563/or/ Transition_to_adulthood_in_Georgia.pdf (accessed Io.IO2020).

Thompson, Edward Palmer. 197I. "The Moral Economy of the English Crowd in the Eighteenth Century." Past \& Present 50, 76-136.

Tsing, Anna. 20I2. "Unruly edges: mushrooms as companion species." Environmental Humanities I, I4I-I54.

Tsitsishvili, Nino. 2006. "'A man can sing and play better than a woman': Singing and patriarchy at the Georgian Supra feast." Ethnomusicology 50 (3), 452-493.

Tuite, Kevin. 2005. "The autocrat of the banquet table: the political and social significance of the Georgian supra." http://www.mapageweb.umontreal.ca/tuitekj/publications/Tuite-supra.pdf (accessed IO.IO.2020).

Weiner, Elaine S. 2005. "No (Wo)Man's Land: the post-socialist purgatory of Czech female factory workers." Social Problems 4(52), 572-592.

Yalçın-Heckmann, Lale. 20IO. Rural property and economy in postsocialist Azerbaijan. Halle/Saale, Berlin: Lit Verlag.

\section{AUTHOR'S CONTACT:}

Katarzyna E. Król

Graduate School for Social Research, Polish Academy of Sciences

E-mail: kkrol@ifis.edu.pl

ORCID: 0000-0002-II3I-8247 